DOI: http://dx.doi.org/10.18290/rh20689-9

MAŁGORZATA RELIGA

\title{
WSPÓŁCZESNA POLITYKA CHIN WOBEC RELIGII
}

\author{
CONTEMPORARY CHINESE POLICY \\ CONCERNING RELIGION
}

\begin{abstract}
The last forty years of Reform and Opening Up in China have brought many changes and corrections in the policies of the Chinese state towards religion. Those policies were incorporated into the overall state policy and recognised as an important part of the Party's work. The theoretical basis for the state religious policy is the so-called "theory of religion with Chinese characteristics". In 2015, Xi Jinping for the first time stated the need for "persisting in the Sinicisation of religion". His particular understanding of "Sinicisation" applies not only to the foreign religions such as Islam or Christianity, but to indigenous Daoism as well, which implies that, in the modern official parlance of the PRC, the term "Sinicisation of religion" has a new meaning, different from the more traditional understandings of the word. In fact, it has been translated in English-language publications as the "Chinafication of religion"; an even more appropriate translation, however, would be the "PRC-isation of religion", as the afore-mentioned "Sinicisation" most of all means obedience to the CCP's rule and "adaptation to the needs of the socialist society". This article outlines the evolution of the theory of religion with Chinese characteristics as it is understood and presented in official publications, and attempts to analyse the scope of the prescribed "Sinicisation of religion" in modern China.
\end{abstract}

Key words: religion in China; sinicization of religion; theory of religion with Chinese characteristics; Xi Jinping; Chinese policy on religion; religion and politics in China.

Niniejszy artykuł jest opisem chińskiej polityki wobec religii w zgodzie $\mathrm{z}$ tym, jak jest ona oficjalnie formułowana w samych Chinach, rozpoczynając od przedstawienia teoretyczno-ideologicznej bazy tej polityki, czyli „socjalistycznej teorii religii z chińską specyfiką" (Zhongguo tese zongiao lilun 中国特色宗教理论). Opis oparty jest na dokumentach i odgórnie apro-

Dr MaŁgorzata Religa - Uniwersytet Warszawski, Wydział Orientalistyczny, Zakład Sinologii; e-mail: malgorzata.religa@uw.edu.pl. ORCID: https://orcid.org/0000-0002-9676-3146. 
bowanych artykułach prasowych lub książkowych zamieszczonych na stronie internetowej Krajowego Departamentu ds. Religijnych (Guojia zongjiao shiwuju 国家宗教事务局, SARA). Ta instytucja, podległa Radzie Państwowej, na początku 2018 r. została, w ramach zapowiedzianej w czasie XIX Zjazdu KPCh reformy instytucji partyjnych i państwowych, wcielona do Departamentu Zjednoczonego Frontu Pracy KC KPCh.

W rozumieniu chińskich dokumentów termin „religia” odnosi się przede wszystkim do pięciu oficjalnie uznanych religii działających w Chinach: buddyzmu, taoizmu, islamu, katolicyzmu i protestantyzmu. Wszystkie te religie dysponują dojrzałymi, wielowiekowymi doktrynami, wielkim piśmiennictwem, skodyfikowaną liturgią, mniej lub bardziej jasno wyodrębnionym klerem i miejscami kultu, a w kontaktach $\mathrm{z}$ władzami mają oficjalną reprezentację w postaci takich organizacji, jak: Chińskie Stowarzyszenie Buddyjskie, Chińskie Stowarzyszenie Taoistyczne, Chińskie Stowarzyszenie Islamskie, Patriotyczne Stowarzyszenie Katolików Chińskich, Konferencja Biskupów Kościoła Katolickiego w Chinach, Narodowy Komitet Patriotycznego Ruchu Trzech Niezależności Kościołów Protestanckich oraz Rada Chrześcijan Chińskich. Takie pojmowanie religii zostawia poza jej obszarem wiele synkretycznych i nieco amorficznych wierzeń i praktyk, zaliczanych zwykle do „religii ludowych". W nowszych publikacjach oficjalnych dotyczących kwestii religijnych termin „religie ludowe” zaczyna się jednak pojawiać coraz częściej, co wskazuje, że i ten rodzaj religijności zaczyna być zauważany i włączany do obszaru planowej „pracy religijnej”. „Praca religijna” (zongjiao gongzuo 宗教工作) to przyjęta w oficjalnym języku nazwa oznaczająca zespół państwowych działań i rozwiązań praktycznych (w tym regulacji prawnych) w odniesieniu do religii. Jakkolwiek dosłowne tłumaczenie tego terminu jest nie tylko chropawe, ale nawet potencjalnie mylące, zdecydowałam się zachować je w tym artykule jako cześć oficjalnej chińskiej terminologii partyjnej i państwowej. Częścią tej terminologii są także takie powtarzające się wyrażenia, jak „kręgi religijne” lub „kadra religijna” czy sama „socjalistyczna teoria religii z chińską specyfiką”, nawiązująca do terminu „socjalizm z chińską specyfiką".

W porównaniu z okresem sprzed 1978 r., po wprowadzeniu polityki reform i otwarcia, ogólna sytuacja religii w Chinach niewątpliwie uległa poprawie. Przykładem tego jest chociażby artykuł 36 Konstytucji ChRL, który od 1982 r. gwarantuje obywatelom wolność religii i wyznania, zakazuje jakiejkolwiek dyskryminacji na podstawie wyznawania (bądź niewyznawania) jakiejś religii i stwierdza, za państwo otacza opieką „,normalną dzia- 
łalność religijną". To sformułowanie otwiera oczywiście pytanie, co to jest „normalna działalność religijna” oraz kto i na jakich podstawach tę normalność definiuje. Podstawowym aspektem relacji między państwem a religią jest pozostająca poza wszelką dyskusją nadrzędna pozycja partii; partia, nie wchodząc w zasadzie w dyskusje światopoglądowe, ma obowiązek w tej relacji odgrywać rolę przewodnią i aktywną, tzn. ma „aktywnie prowadzić religie ku adaptacji do społeczeństwa socjalistycznego". To partia - jako autorka socjalistycznej teorii religii z chińską specyfiką - jest ostatecznym arbitrem „normalności” bądź „nienormalności” życia religijnego. Przewodnia rola partii i konieczność przejmowania przez nią inicjatywy w relacji $\mathrm{z}$ religiami została bardzo silnie podkreślona przez Xi Jinpinga na konferencji z okazji dwustulecia urodzin Marksa w maju 2018 r.

Polityka Chin wobec religii nie jest zbiorem przypadkowych rozwiązań; jest to polityka świadoma i w swoim podstawowym kierunku dość konsekwentna, chociaż podlegająca różnym modyfikacjom i z różnie rozkładanymi akcentami w różnych okresach. Chińskie omówienia „socjalistycznej teorii religii z chińską specyfiką" podkreślają, że jest ona systemem otwartym, podlegającym uzupełnieniom i korektom w zależności od realnych uwarunkowań wewnętrznych i międzynarodowych. Przykładowo: konflikty o podłożu etniczno-religijnym w dawnej Jugosławii po rozpadzie bloku socjalistycznego w Europie uświadomiły Chinom, że w sytuacji rozluźnionej kontroli ideologicznej religia wciąż pozostaje siłą, z którą należy się liczyć i która potrafi zagrozić stabilności porządku politycznego. Generalnie rzecz biorąc, można stwierdzić, że ostatecznym celem socjalistycznej teorii religii z chińską specyfiką i opartej na niej „pracy religijnej”, czyli całości polityki religijnej w Chinach, jest znalezienie najskuteczniejszych metod kontroli religii i jak najpełniejszego podporządkowania jej państwu.

\section{ETAPY KSZTAŁTOWANIA SIE SOCJALISTYCZNEJ TEORII RELIGII Z CHIŃSKĄ SPECYFIKĄ ${ }^{1}$}

Historia kształtowania się socjalistycznej teorii religii z chińską specyfiką przedstawiana jest $\mathrm{w}$ etapach zgodnie $\mathrm{z}$ periodyzacją najnowszej historii politycznej według ,pokoleń centralnego kolektywu kierowniczego”. Poczy-

\footnotetext{
${ }^{1}$ Na podstawie: Zhongguo tese shehui zhuyizongjiao lilun de tansuo licheng 中国特色社会主义 宗教理论的探索历程 | thum. pol.: „Historia socjalistycznej teorii religii z chińską charakterystyką”.
} 
nając od drugiego pokolenia, jest ona traktowana jako element całości ideologii politycznej związanej z centralną postacią danego okresu - jest więc częścią teorii Deng Xiaopinga, idei Trzech Reprezentacji Jiang Zemina, idei naukowego rozwoju Hu Jintao oraz socjalizmu z chińską specyfiką w nowej erze Xi Jinpinga.

Podany dalej opis stanowi wyciąg $\mathrm{z}$ oficjalnych chińskich opracowań i przedstawiony jest $\mathrm{z}$ zachowaniem oryginalnej interpretacji i sformułowań. Opracowania te podają obowiązującą wykładnię historii, według której nie ma sprzeczności między realizowaniem „polityki wolności religijnej” a usuwaniem ludzi i tradycji politycznie niewygodnych, określanych np. mianem „sił imperialistycznych i kontrrewolucyjnych”. Ta wykładnia pomija milczeniem (lub co najwyżej kwituje jednym zdaniem) planowe prześladowania religii z okresu bezpośrednio po utworzeniu ChRL czy z czasu rewolucji kulturalnej. Pokazuje także dość jasno, że partia co prawda zaakceptowała i wcieliła do swojego arsenału pojęciowego koncepcję wolności religijnej, jest to jednak wolność ,z chińską specyfiką”, podlegająca ograniczeniom ideologicznym. Kierując się zasadą wolności religijnej, partia niczego religiom nie narzuca, a tylko „wspomaga je w reformowaniu” doktryn czy obyczajów w zgodzie z własnymi potrzebami.

Jednocześnie w tym opisie jasno wybite są najważniejsze momenty każdego z etapów, poczynając od drugiego pokolenia kolektywu kierowniczego. Były to: (1) podstawy samookreślenia państwa wobec religii i umieszczenie wolności religii w artykule 36 konstytucji za Deng Xiaopinga, (2) uznanie konieczności opracowania przepisów prawa dotyczących działalności religijnej i ,aktywne prowadzenie religii ku adaptacji do społeczeństwa socjalistycznego” za Jiang Zemina, (3) koncepcja „harmonii religijnej” i wcielenie „pracy religijnej” do całości strategicznego planowania za Hu Jintao i wreszcie (4) zwiększenie nacisku na rozwiązania prawne oraz na aktywne przewodnictwo partii w kwestiach religijnych, a także koncepcja „sinizacji religii” za Xi Jinpinga.

Opis ten dobrze pokazuje również coraz większą precyzyjność języka używanego odnośnie do kwestii religijnych, co jest z kolei odzwierciedleniem coraz jaśniej definiowanego stanowiska władz wobec religii i coraz bardziej szczegółowych zasad postępowania wobec niej. 
ETAP PIERWSZY - MAO ZEDONG I CENTRALNY KOLEKTYW KIEROWNICZY PIERWSZEGO POKOLENIA

W okresie rewolucji nowodemokratycznej Komunistyczna Partia Chin nakreśliła podstawowe zasady wolności religii i wyznania oraz rozdzielenia państwa i religii w takich dokumentach, jak: „Projekt konstytucji Radzieckiej Republiki Chińskiej” (1934), „O rządzie koalicyjnym” (1945) oraz „Wspólny Program Ludowej Politycznej Konferencji Konsultatywnej Chin" (1949).

- Partia stwierdziła też, że jej członkowie mogą tworzyć zjednoczony front w działaniach antyimperialistycznych i antyfeudalnych z niektórymi wyznawcami idealizmu, a nawet $\mathrm{z}$ niektórymi przedstawicielami kręgów religijnych. Partia opowiedziała się za tym, aby wszystkie mniejszości etniczne miały swobodę w utrzymywaniu lub reformowaniu swoich zwyczajów i przekonań religijnych.

Tak w okresie rewolucji, jak i w okresie budowy socjalizmu partia wspierała kręgi religijne w usuwaniu $\mathrm{z}$ ich szeregów sił imperialistycznych, promowała powstanie niezależnego i samorządnego Kościoła oraz politykę „trzech niezależności”, dzięki której katolicyzm i protestantyzm stały się niezależnymi religiami kierowanymi przez chińskich wiernych; wspomagała patriotów z kręgów religijnych w demokratycznych reformach systemów religijnych, zniesieniu feudalnych przywilejów religijnych i opresyjnego systemu wyzysku, a także w ujawnieniu sił kontrrewolucyjnych działających pod przykrywką religii.

- Partia sformułowała koncepcję „pięciu cech” religii: długoterminowości, masowości, złożoności, jej charakteru narodowego i jej charakteru międzynarodowego. Partia rozwinęła teorię współpracy z kręgami religijnymi, opierając się na założeniu, że wierzenia religijne nie wiążą się z kwestiami politycznymi.

EtaP DRUgi - Deng Xiaoping I Centralny Kolektyw Kierowniczy DRUGIEGO POKOLENIA

1978 r. Po Trzecim Plenum Centralnego Komitetu KPCh XI kadencji, Deng Xiaoping wraz z centralnym kolektywem drugiego pokolenia dokonał podsumowania pozytywnych i negatywnych doświadczeń partii w kwestiach religijnych od czasu powstania Nowych Chin i sformułował 
serię wytycznych w odniesieniu do religii, tworząc podstawy socjalistycznej teorii religii z chińską specyfiką.

- 1981 r. „Uchwała Komitetu Centralnego KPCh w sprawie kilku kwestii historycznych od czasu utworzenia Chińskiej Republiki Ludowej” przyjęta na Szóstym Plenum KC KPCh XI kadencji stwierdza, że konieczne jest dalsze wdrażanie polityki wolności wyznania, pod warunkiem spełnienia przez wierzących czterech podstawowych zasad: niewystępowania przeciwko marksizmowi-leninizmowi, niewystępowania przeciwko myśli Mao Zedonga, nieingerowania w politykę i nieingerowania w edukację.

- 1982 r. Władze centralne opublikowały dokument zatytułowany „Podstawowe poglądy i podstawowe wytyczne w kwestiach religijnych w Chinach w okresie socjalizmu" (znany także jako Dokument 19)², w których zawarto informacje na temat religii jako zjawiska historycznego, polityki partii wobec religii, patriotycznych organizacji religijnych, postawy członków partii wobec religii, relacji z religijnymi mniejszościami narodowymi, działalności kontrrewolucyjnej pod przykrywką religii, roli partii i organów państwowych w traktowaniu kwestii religijnych.

- W Konstytucji Chińskiej Republiki Ludowej znalazł się przyjęty przez Ogólnochińskie Zgromadzenie Przedstawicieli Ludowych artykuł 36, który stwierdza: „Obywatele Chińskiej Republiki Ludowej mają prawo wolności religii i wyznania. Żadna instytucja państwowa, grupa społeczna ani jednostka nie może nakłaniać obywateli do wyznawania bądź niewyznawania religii i nie może dyskryminować obywateli na podstawie wyznawania bądź niewyznawania religii. Nikt nie może wykorzystywać religii do podważania porządku społecznego, działania na szkodę zdrowia bądź utrudniania funkcjonowania państwowego systemu edukacji. Grupy religijne i wszelkie sprawy religijne nie podlegają wpływom obcych sił".

Zrehabilitowano przypadki niesłusznego traktowania z okresu rewolucji kulturalnej, naprawiono błędy lewicowego odchylenia i wznowiono działalność patriotycznych organizacji religijnych, dokonano postępu w implementacji polityki dotyczącej własności nieruchomości grup religijnych i otwarto nową kartę $\mathrm{w}$ przyjaznych kontaktach zagranicznych między religiami.

\footnotetext{
${ }^{2}$ Fragmenty tego bardzo ważnego dokumentu dostępne są na Internecie po angielsku: „The People' Republic of China: Document 19: The Basic Viewpoint on the Religious Question During Our Country's Socialist Period (selections)".

Całość tekstu po chińsku: Guanyu woguo shehuizhuyi shiqi zongjiao wentí de jiben guandian he jiben zhengce 矢于我国社会主义时期宗教问题的基本观点和基本政策 | thum. pol.: „Podstawowe poglądy i podstawowe wytyczne w odniesieniu do kwestii religijnych w Chinach w okresie sojalizmu".
} 
EtAP TRZECI - JIANG ZEMIN I CENTRALNY KOLEKTYW KIEROWNICZY TRZECIEGO POKOLENIA

Po Czwartym Plenum KC KPCh trzynastej kadencji, Jiang Zemin wraz z centralnym kolektywem kierowniczym trzeciej generacji dokonał głębokiej analizy kwestii religijnych w aspekcie teoretycznym i praktycznym w sytuacji głębokich zmian politycznych w świecie post-zimnowojennym i coraz wyraźniejszych problemów etnicznych i religijnych oraz w warunkach reformy, otwarcia i modernizacji w Chinach.

W 1990 r. KC KPCh oraz Rada Państwowa zwołały Ogólnonarodową Konferencję Pracy Religijnej, po której ogłoszona została „Nota na temat kilku kwestii dot. dalszego doskonalenia pracy religijnej”, w której jasno sformułowano przełomowe wezwanie do regulacji spraw religijnych w oparciu o prawo.

W 1993 r. na Ogólnokrajowej Konferencji Zjednoczonego Frontu Pracy Jiang Zemin sformułował "trzy punkty" wytyczające kierunek pracy religijnej:

- całkowite i prawidłowe wdrażanie wytycznych Partii w pracy religijnej;

- wzmocnienie regulacji spraw religijnych w oparciu o prawo;

- aktywne kierowanie religii ku adaptacji do społeczeństwa socjalistycznego.

W 1994 r. Rada Państwowa zatwierdziła Przepisy administracyjne dotyczące działalności religijnej cudzoziemców na terytorium Chińskiej Republiki Ludowej (zarządzenie nr 144 Rady Państwowej) oraz Przepisy administracyjne dotyczące miejsc kultu religijnego (zarządzenie nr 145 Rady Państwowej).

W 2001 r. KC KPCh oraz Rada Państwowa ponownie zwołały Ogólnokrajową Konferencję Pracy Religijnej, na której Jiang Zemin wygłosił przemówienie zatytułowane „O kwestiach religijnych”. W tym przemówieniu dokonał analizy długotrwałej natury religii, jej szczególnej złożoności i jej masowego charakteru oraz sformułował wytyczne pracy religijnej w „,czterech punktach”:

- kompleksowa realizacja polityki Partii odnośnie wolności religii i wyznania;

- regulowanie kwestii religijnych w oparciu o prawo;

- aktywne kierowanie religii ku adaptacji do społeczeństwa socjalistycznego;

- przestrzeganie zasady niezależności i autonomii religii. 
W 2002 r. ogłoszono „Decyzję Komitetu Centralnego Komunistycznej Partii Chin i Państwowej Rady dotyczącą zintensyfikowania pracy religijnej”3.

ETAP CZWARTY - HU JINTAO I CZWARTY CENTRALNY KOLEKTYW KIEROWNICZY

- Po XVI Zjeździe Komunistycznej Partii Chin Hu Jintao i Komitet Centralny Partii wprowadzili do socjalistycznej teorii z chińską charakterystyką bazę teoretyczną zaczerpniętą z teorii naukowego rozwoju.

- W 2004 r. KC KPCh i Rada Państwowa zwołały Ogólnonarodową Konferencję Pracy Religijnej, na której „cztery punkty” po raz pierwszy zostały jasno określone jako podstawowe wytyczne pracy religijnej partii.

- W listopadzie tego samego roku Rada Państwowa ogłosiła pierwszy całościowy zbiór przepisów prawnych i administracyjnych dotyczących działalności religijnej w Chińskiej Republice Ludowej: „Regulacje dotyczące religii" (rozporządzenie $\mathrm{nr} 426$ ).

- W 2006 r., po Szóstym Plenum KC KPCh szesnastej kadencji, partia wezwała wierzących do ,jak najpełniejszego odgrywania aktywnej roli w promowaniu harmonii społecznej, rozwoju gospodarczego i społecznego, oraz rozkwitu kulturalnego", tym samym pogłębiając bazę teoretyczną dla polityki aktywnego kierowania religii ku adaptacji do społeczeństwa socjalistycznego.

- W 2006 r. na Ogólnokrajowej Konferencji Zjednoczonego Frontu Pracy Hu Jintao oświadczył, że relacje religijne należą do pięciu głównych relacji w sferze politycznej i społecznej, i jako takie włączone są do całości pracy partii i państwa; konieczne jest dążenie do osiągnięcia harmonii między religią a społeczeństwem. Koncepcja „harmonii religijnej” została ponownie podkreślona w 2016 r. w raporcie XVIII Zjazdu KPCh., w którym uznano znaczenie pracy religijnej z perspektywy strategicznej.

\section{ETAP PIĄTY - XI JINPING I PIĄTY CENTRALNY KOLEKTYW KIEROWNICZY}

- W 2012 r. w raporcie XVIII Zjazdu KPCh stwierdza się, że konieczne jest kompleksowe wdrożenie podstawowych zasad pracy religijnej partii, promowanie harmonijnych stosunków religijnych oraz pozytywnej roli kręgów religijnych w rozwoju gospodarczym i społecznym. Chiński sen o wielkim odrodzeniu narodu chińskiego zapewnia szerszą przestrzeń dla uruchomienia pozytywnych działań i aktywnej roli kręgów religijnych.

\footnotetext{
${ }^{3}$ Zhonggong zhongyang guowuyuan guanyu jiaqiang zongjiao gongzuo de jueding 中共中央国 务院关于加强宗教工作的决定 | thum. pol.: Decyzja Komitetu Centralnego Komunistycznej Partii Chin i Państwowej Rady dotycząca zintensyfikowania pracy religijnej.
} 
Xi Jinping podkreślił, że partia w swoim traktowaniu kwestii religijnych musi zachować postawę przewodnictwa i inicjatywy, co przyczyni się do korygowania nieporozumień dotyczących religii i jasno wskaże kierunek pracy religijnej („Dang de shiba da yilai”).

2015 r. Na Konferencji Centralnego Zjednoczonego Frontu Pracy Xi Jinping po raz pierwszy sformułował konieczność utrzymania kierunku sinizacji religii i wprowadził zmiany w kolejności „czterech punktów”, która wygląda obecnie następująco:

- kompleksowa realizacja polityki Partii odnośnie wolności religii i wyznania;

- regulowanie kwestii religijnych w oparciu o prawo;

- przestrzeganie zasady niezależności i autonomii religii;

- aktywne kierowanie religii ku adaptacji do społeczeństwa socjalistycznego.

Aktywne prowadzenie religii w kierunku adaptacji do społeczeństwa socjalistycznego obejmuje „cztery konieczności”:

- utrzymania kierunku sinizacji religii;

- polepszenia poziomu prawodawstwa w odniesieniu do pracy religijnej;

- dialektycznego postrzegania społecznej roli religii;

- przywiązywania wagi do roli odgrywanej przez kręgi religijne.

Utrzymanie kierunku sinizacji religii obejmuje:

- przewodzenie za pomocą zasadniczych wartości socjalizmu;

- nasycanie wszystkich religii w Chinach kulturą chińską;

- wspieranie kręgów religijnych w nauczaniu i interpretacji swoich doktryn zgodnym z postępem społecznym i wymogami czasów;

- zdecydowane niedopuszczanie do infiltracji religii przez ideologie zachodnie;

- świadome przeciwstawianie się wpływom i trendom ekstremizmu religijnego.

Polepszenie poziomu prawodawstwa $\mathrm{w}$ odniesieniu do pracy religijnej wymaga:

- utrzymania ochrony prawnej legalnej działalności religijnej;

- niedopuszczania do nielegalnej działalności religijnej;

- wyrugowania ekstremizmu;

- niedopuszczania do infiltracji;

- walki z przestępstwami.

\footnotetext{
${ }^{4}$ Zasadnicze wartości socjalizmu (shehuizhui hexin jiazhiguan 社会主义核心价值观) to: 1. Wartości państwowe - dobrobyt, demokracja, cywilizacja, harmonia; 2. Wartości społeczne wolność, równość, sprawiedliwość, rządy prawa; 3. Indywidualne wartości obywatelskie - patriotyzm, zaangażowanie, uczciwość, przyjazność.
} 
Dialektyczne postrzeganie społecznej roli religii oznacza mobilizowanie jej czynników pozytywnych i eliminowanie negatywnych. Odgrywanie pozytywnej roli przez religię wymaga skierowania religii na drogę promowaniu rozwoju gospodarczego, harmonii społecznej, rozkwitu kulturalnego, jedności narodowej i zjednoczenia ojczyzny.

Przywiązywanie wagi do roli odgrywanej przez kręgi religijne wymaga wykształcenia grupy reprezentantów religii, lojalnych pod względem politycznym i biegłych w kwestiach religijnych, którzy będą wspierać partię i państwo w pracy religijnej.

- W kwietniu 2016 r. odbyła się Ogólnokrajowa Konferencja Pracy Religijnej z udziałem Xi Jinpinga, który w swoim przemówieniu („Xi Jinping chuxi guango") stwierdził m.in. że

- konieczne jest utrzymanie przewodniej roli partii w kwestiach religijnych, przestrzeganie rozdziału państwa i religii, utrzymanie zasady nieingerowania przez religię $\mathrm{w}$ takie sprawy państwowe jak administracja, edukacja i wymiar sprawiedliwości, utrzymanie kierowniczej roli państwa w sprawach religijnych dotyczących interesów narodu i państwa;

- konieczne jest utrzymanie kierunku sinizacji religii, co jest jedyną drogą rozwoju religii w Chinach i obejmuje kształcenie kręgów religijnych w duchu zasadniczych wartości socjalizmu.

We wrześniu 2017 r. ogłoszono zmienioną i poprawioną wersję Regulacji dotyczacych religii, która weszła w życie w lutym 2018 r.

W styczniu 2018 r. odbyła się krajowa konferencja dyrektorów departamentów religii, na której m.in. uznano potrzebę rozwoju współpracy religijną z Hongkongiem, Tajwanem i Makao, a także Rosją i państwami Nowego Jedwabnego Szlaku („Nian quanguo zongjiao”).

\section{RELACJA PARTII I RELIGII}

Komunistyczna Partia Chin jednoznacznie oczekuje od swoich członków „ateistycznego światopoglądu i tego, że nie będą wyznawcami żadnej religii, ani nie będą uczestniczyć w żadnych praktykach religijnych. Członkowie partii muszą posiadać przekonania komunistyczne, dobrze znać i rozumieć wytyczne polityki partii w kwestiach religii i być w pełni świadomi, że niewyznawanie żadnej religii jest najbardziej podstawowym warunkiem przynależności do partii. Należy strzec partii przed ideologicznym osłabieniem ze strony religii i należy utrzymać ideologiczną nieskazitelność i postępowość członków partii” (,Jiaqiang dang dui”; tłum. pol. M.R.). 
Jednocześnie jednak, jak stwierdzono w opisie etapów kształtowania się socjalistycznej teorii religii z chińską specyfiką, partia uznaje długotrwały i masowy charakter religii. Od sformułowania przez Jiang Zemina teorii Trzech Reprezentacji za klasową bazę KPCh uznaje się nie tylko robotników, chłopów, inteligencję, kadrowych działaczy, żołnierzy i oficerów ChALW, ale także nowe klasy społeczne, np. prywatnych przedsiębiorców. Masowy charakter religii oznacza, że także wierzący muszą zostać włączeni do bazy oparcia KPCh, z czego wynika konieczność uznania zasady, że „wspólnota interesów politycznych i ekonomicznych mas wierzących i niewierzących jest dużo istotniejsza niż dzielące ich różnice” (,Zhizhang dang yu zongjiao"; tłum. pol. M.R.).

Uznanie religii za zjawisko, które wymaga włączenia do całościowego planu rządzenia krajem i konieczność „aktywnego prowadzenia jej ku adaptacji do społeczeństwa socjalistycznego", wymaga wypracowania zarówno ogólnych, jak i szczegółowych reguł współistnienia partii i religii, takich jak:

1. Konieczność pełnej jednomyślności oraz zrozumienia strategicznego i ogólnopaństwowego znaczenia pracy religijnej na wszystkich szczeblach władz partyjnych i państwowych. Właściwość bądź niewłaściwość podejmowanych przez nie kroków oceniana musi być według ich zgodności z wytycznymi Partii i z przepisami prawa, a także według tego, czy zdolne są przeciwdziałać i prawidłowo rozwiązywać antagonizmy etniczne i religijne.

2. Kadry kierownicze wszystkich szczebli mają obowiązek studiowania socjalistycznej teorii religii z chińską specyfiką.

3. Kadry kierownicze wszystkich szczebli mają obowiązek zdobywania wiedzy dotyczącej religii, powinny także mieć ścisły kontakt, a nawet przyjaźnić się z przedstawicielami kręgów religijnych, znać ich opinie i słuchać ich sugestii. W regionach zamieszkałych przez mniejszości narodowe, w których niemal całość populacji wyznaje jakąś religię, członkowie Partii najniższego szczebla uczestniczą w niektórych masowych wydarzeniach o charakterze religijnym, należących do lokalnej tradycji; przestrzegając narodowych obyczajów lokalnych, należy jednak wyraźnie oddzielić je od kwestii ideologicznych.

4. Takie organizacje, jak związki zawodowe, Liga Młodzieży Komunistycznej, Ogólnochińska Federacja Kobiet itd., powinny wspierać pracę religijną w zgodzie z wytycznymi Departamentu Zjednoczonego Frontu Pracy.

5. Władze partyjne i państwowe wszystkich szczebli powinny przywiązywać wielką wagę do kształcenia kadr religijnych, które są niezbędne do właściwej realizacji pracy religijnej. Ludzie ci powinni być pragmatyczni, 
świadomi wyzwań nowej sytuacji, posiadać ugruntowane przekonania polityczne i dysponować głęboką wiedzą w kwestiach religijnych.

6. Konieczne jest utworzenie trzypoziomowej sieci jednostek administracyjnych na szczeblu powiatu, miasteczka (zhen 镇) i wsi (xiang 乡). Na poziomie powiatu powinna znajdować się instytucja odpowiedzialna za pracę religijną, wykonywaną przez specjalny personel w miasteczkach i wsiach. Podobne struktury powinny znajdować się w dużych miastach (shi 市) na poziomie dzielnic i dystryktów, a także w szkołach i przedsiębiorstwach.

7. Biura propagandy podległe władzom partyjnym i państwowym wszystkich szczebli są zobowiązane do szerzenia wśród ludu, a przede wszystkim wśród młodzieży, wiedzy na temat materializmu dialektycznego, materializmu historycznego i ateizmu, a także naukowej wiedzy na temat zjawisk naturalnych, ewolucji społeczeństwa, chorób, śmierci i losu. Konieczne jest szerzenie wiedzy na temat socjalistycznej teorii religii z chińską specyfiką oraz przepisów prawa w odniesieniu do religii.

8. Szkoły partyjne oraz szkoły administracji każdego szczebla powinny do swego programu nauczania włączyć socjalistyczną teorię religii z chińską specyfiką. Uczelnie wyższe i uniwersytety powinny wzmocnić nauczanie ateizmu i materializmu oraz dokładać starań, by krzewić wśród studentów ducha naukowego. Konieczne jest nasilenie rozpowszechniania marksistowskiej koncepcji religii oraz wytycznych polityki partii wobec religii. Należy także uruchomić fakultatywne kursy religioznawstwa, dostarczające podstaw wiedzy o religii, zachęcać studentów do stosowania światopoglądu i metody marksistowskiej w zgłębianiu religii, oraz do świadomego przeciwstawiania się wszelkim naleciałościom teistycznym.

Dyrektywy te ukazują, że mimo zaakceptowania „długotrwałego i masowego charakteru religii" partia i państwo nie rezygnują z walki o jak najszybszą światopoglądową unifikację społeczeństwa. Dla osiągnięcia tego celu konieczna jest, po pierwsze, całkowita jednomyślność i konsekwencja w realizowaniu wytycznych partii; po drugie, planowe wpajanie społeczeństwu światopoglądu „ateistycznego i materialistycznego"; po trzecie wreszcie, zgodne z zaleceniami Xi Jinpinga przejmowanie kontroli nad religiami od wewnątrz przez wychowanie „kadr religijnych” lojalnych wobec polityki partii.

\section{POZYTYWNA ROLA RELIGII}

Dokumenty i artykuły podkreślają, że „,budowa socjalizmu z chińską specyfiką i realizacja chińskiego snu o wielkim odrodzeniu narodu chińskiego wy- 
magają mobilizacji wszelkich dostępnych sił i zgromadzenia wszelkich pozytywnych czynników. Od XVI plenum KC KPCh, Partia nieprzerwanie wzywa religie do jak najpełniejszego odgrywania pozytywnej roli w promowaniu harmonii społecznej oraz w rozwoju gospodarczym i rozwoju kulturalnym" („Guojia zongjiao”; thum. pol. M.R.).

Mówiąc konkretniej, religie mają wykorzystać swoje doświadczenia do „promowania patriotyzmu, wspierania przewodniej roli partii i systemu socjalistycznego, aktywnego włączenia się do budowy średniozamożnego społeczeństwa, podjęcia wysiłków na rzecz udoskonalenia i rozwoju socjalistycznej kultury z chińską specyfiką, przyczynienia się do ochrony jedności narodowej, stabilności społecznej i wielkiego zadania zjednoczenia ojczyzny" („Guojia zongjiao”; tłum. pol. M.R.). Innymi słowy, religia może spełniać role pozytywną tylko wtedy, gdy stanie się jeszcze jednym narzędziem polityki państwa i gdy uzna zwierzchność tej polityki nad sobą. Swoje zadanie służby społeczeństwu religia może i powinna zatem realizować w następujących obszarach:

1. UCZESTNICTWO W ROZWOJU GOSPODARCZYM. Religie mogą mieć bezpośredni lub pośredni wpływ na rozwój gospodarczy poprzez kształtowanie u wyznawców właściwej postawy wobec produkcji i konsumpcji, mogą także przyczynić się do promowania turystyki i do rozwoju sektora kulturalnego.

2. Promowanie JEDNoŚCI NAROdOWEJ. Niektóre religie w Chinach mają wyraźny narodowy charakter, a wiele mniejszości narodowych wyznaje religie, która ściśle związane są z ich kulturą. Należy zachęcać kręgi religijne do promowania idei patriotyzmu, jedności i równości oraz do wspierania u wierzących świadomości państwowej, prawnej i obywatelskiej.

3. Promowanie ZJEDNOCZENIA OJCZYZnY. Ponieważ buddyzm i taoizm w Chinach kontynentalnych i na Tajwanie mają te same korzenie, należy zachęcać do zacieśnienia kontaktów między wyznawcami tych religii na kontynencie i na Tajwanie do wspólnego promowania patriotycznych tradycji oraz do pogłębienia wzajemnego zrozumienia po obu stronach Cieśniny Tajwańskiej.

4. Promowanie tradycyjnej KUltury. Religia jako część kultury miała głęboki wpływ na politykę, filozofię, etykę, literaturę, język, muzykę, sztukę, architekturę, medycynę, a także naukę i technologię. Należy czerpać z jej najlepszych dokonań w dziedzinie kultury i przekazywać jej materialny i niematerialny dorobek poprzez wydawanie książek, ochronę zabytków itd.

5. UdZIELANIE POMOCY I WSPARCIA PSYCHOLOGICZNEGO. Gwałtowny rozwój Chin wpłynął na zaostrzenie konkurencji i zwiększenie poczucia niepew- 
ności wśród ludzi. Wśród wierzących religia może odegrać pozytywną rolę w łagodzeniu napięć psychologicznych, koniecznym jest więc zachęcanie kadr religijnych do udzielania masom pomocy w prawidłowym przystosowaniu się do współczesnych warunków.

6. Podnoszenie poziomu moralności. Moralne idee religijne mają wiele elementów wspólnych z moralnością socjalistyczną, dlatego konieczne jest zachęcanie religii do promowania tych właśnie wartości i do wychowywania swoich wiernych na obywateli przestrzegających prawa, uczciwych, słownych, kulturalnych i altruistycznych.

7. Rozwijanie „DYPlomacji Ludowej”. Pięć głównych religii w Chinach łączą więzi ze współwyznawcami za granicą i stanowią one ważny kanał prywatnych kontaktów. Przy zachowaniu zasady niezależności i samorządności kręgi religijne powinny aktywnie kontynuować wymianę i współpracę w sprawach religijnych i działać na rzecz przyjaźni między narodami.

8. Angażowanie się w dZialalność charytatywną. Pięć głównych religii w Chinach ma długą tradycję działalności charytatywnej, którą powinny kontynuować - wspomagać chorych, samotnych, opuszczonych, starych, organizować pomoc finansową dla najuboższych i potrzebujących itd.

9. Promowanie haRMONiI SPOŁECZNEJ. Niektóre z wartości promowanych przez religie pozostają $\mathrm{w}$ zgodzie $\mathrm{z}$ zasadniczymi wartościami socjalistycznymi. Należy zachęcać religie do promowania idei harmonii, oraz do realizowania jej w relacjach ze społeczeństwem i w relacjach między poszczególnymi wyznaniami.

10. OCHRONA ŚRODOWISKA. W doktrynach religijnych znajduje się wiele idei dotyczących harmonijnej koegzystencji człowieka i natury. Należy zachęcać wspólnoty religijne do usystematyzowania nauczania na temat ochrony środowiska oraz do kształcenia u wyznawców kultury ekologicznej.

Ta lista, wyraźnie pochodząca $\mathrm{z}$ obiektywnej analizy różnych funkcji społecznych rzeczywiście spełnianych historycznie przez religie (choć niemal wszystkie te funkcje są z punktu widzenia samych religii drugorzędne, były przez nie różnie traktowane i przypisywano im różne znaczenie), jest interesująca jako próba wynegocjowania dla religii miejsca $\mathrm{w}$ państwie, które nie jest neutralne światopoglądowo i którego celem jest ostatecznie całkowite usunięcie religii z życia społecznego. Uznając fakt „długotrwałości” religii i konieczność tymczasowego przynajmniej z nimi współistnienia, państwo skupia się na ich funkcjach w sferze doczesności, pomijając milczeniem to, co stanowi ich istotę, czyli ich wymiar duchowy. 


\section{SINIZACJA RELIGII}

Jak już wspomniano, hasło sinizacji religii zostało po raz pierwszy sformułowanie przez Xi Jinpinga na Konferencji Departamentu Zjednoczonego Frontu Pracy w 2015 r. jako pierwsza z „czterech konieczności” aktywnego kierowania religii ku adaptacji do społeczeństwa socjalistycznego. Sam Xi Jinping wyjaśnił, że „sinizacja” oznacza tutaj nasycanie wszystkich religii w Chinach kulturą chińską, wspieranie kręgów religijnych w nauczaniu i interpretacji swoich doktryn zgodnie z postępem społecznym i wymogami czasów, zdecydowane niedopuszczanie do infiltracji religii przez ideologie zachodnie oraz świadome przeciwstawianie się wpływom i trendom ekstremizmu religijnego, Postulat sinizacji religii jako jedna z kluczowych wytycznych polityki religijnej Chin $\mathrm{w}$ „nowej erze socjalizmu z chińską specyfiką" wymaga jednak dalszego doprecyzowania. Co konkretnie ma znaczyć „nasycanie religii kulturą chińską” i „interpretacja doktryn religijnych w zgodzie z postępem społecznym i wymogami czasów"? Próby zinterpretowania tych wytycznych są obecnie jednym z najczęściej podejmowanych tematów zarówno w publikacjach partyjnych poświęconych kwestiom religijnym, jak i w samych „kręgach religijnych”.

W jednej z takich interpretacji stwierdza się, że obowiązek sinizacji dotyczy nie tylko religii obcych, jak chrześcijaństwo i islam, ale także rodzimych, dotyczy więc także taoizmu, ponieważ ,zatrzymanie się na obecnym etapie musi okazać się niewystarczające. Religia musi zaadaptować się do współczesnego społeczeństwa socjalistycznego z chińską specyfiką i nieprzerwanie dostosowywać się do nowych wymogów czasów i rozwoju" („Ruhe jiedu woguo zōngjiao”; tłum. pol. M.R.).

Sinizacja, rozumiana jako „kierunek, droga i miernik” adaptacji do społeczeństwa socjalistycznego, ma obejmować trzy aspekty:

1) tożsamość polityczną, czyli miłość do kraju, wsparcie dla systemu socjalistycznego i przewodniej roli partii, szacunek dla prawa oraz wytycznych i polityki państwa;

2) adaptację do społeczeństwa, czyli korektę pojęć religijnych, systemów, organizacji itd., przejęcie świeżych inspiracji z rzeczywistości społecznej i dostarczanie pozytywnej energii dla promowania harmonii społecznej i postępu;

3) integrację kulturową, czyli dopasowanie religii do zasadniczych wartości socjalistycznych, interpretowanie doktryn religijnych w zgodzie z potrzebami rozwoju współczesnych Chin i w zgodzie ze wspaniałą tradycyjną kultura chińską. 
Konieczność sinizacji religii uzasadniana jest tu z kilku perspektyw. We fragmencie zatytułowanym „Z perspektywy realiów religii na świecie” autor pisze: „Słabe państwo, mocna religia; mocne państwo, słaba religia. $\mathrm{Na}$ świecie nie ma religii, które od samych swoich początków i z samej swojej natury byłyby ugodowe. (...) Nawet najbardziej schińszczony buddyzm przechodził w Chinach krętą drogę adaptacji i trzykrotnie był zakazywany przez cesarzy, co tylko podkreśla konieczność kierowania religią przez państwo we współczesnych Chinach" (ibid.).

Sam ten fragment wymagałby właściwie dodatkowego wyjaśnienia. Jaki jest stosunek autora do tzw. „trzech klęsk buddyzmu”, w których ostatecznie cesarzom rzeczywiście udało się złamać jego niezależność i potęgę? Czy przywołanie tego przykładu należy traktować jako groźbę wobec religii, czy jako założenie, że religia jest w gruncie rzeczy siłą destrukcyjną, która musi być przez państwo całkowicie ujarzmiona, inaczej może mu wyłącznie zagrozić? W innym fragmencie powiedziane jest wprost, że Departament Zjednoczonego Frontu Pracy KC KPCh

musi przejąć inicjatywę (...) w celu właściwego ukierunkowania sinizacji religii. W szczególności należy prowadzić wspólnoty religijne do sinizacji ich teologii, aby (...) dokonały reinterpretacji tych doktryn, które nie są zgodne z kierunkiem sinizacji, a wszystko, co ześlizgnęło się w kierunku ekstremizmu, musi zostać zdecydowanie usunięte. Tego rodzaju właściwe pokierowanie przedstawicielami wspólnot religijnych ostatecznie poprowadzi do kierowania szerokimi masami wierzących. (Ibid.)

Inna interpretacja („Xin shidai ruhe”) wyraźniej nawiązuje do wymienionej przez Xi Jinpinga konieczności obrony przed ,infiltracją sił zachodnich” i „wpływami ekstremizmu”. Niektóre fragmenty sformułowane są wręcz alarmująco:

Obecnie, w warunkach coraz szerszego otwarcia i globalizacji, światowe religie zintensyfikowały swoje działania na rzecz wzmocnienia wspólnoty wyznawców. Niektóre religie są szczególnie podatne na infiltrację obcych sił, pojawia się $\mathrm{w}$ nich tendencja do alienacji i odwrotnej lokalizacji oraz desinizacji, co zagraża politycznemu i ideologicznemu bezpieczeństwu i stanowi ukryte zagrożenie dla długoterminowej stabilizacji kraju. (...) Utrzymanie kierunku sinizacji religii oznacza efektywną ochronę bezpieczeństwa ideologicznego oraz niedopuszczenie do wykorzystywania religii przez obce siły do walki ideologicznej i prób westernizacji lub kontrolowania Chin. (...) Musimy zdecydowanie się bronić i eliminować wszelkie próby infiltracji i działalności 
wywrotowej, oraz wszelkie akty sabotażu, terroryzmu, separatyzmu i ekstremizmu religijnego. („Xin shidai ruhe”; tłum. pol. M.R.)

Wymienione tu religie szczególnie narażone na wrogie wpływy zewnętrzne to oczywiście chrześcijaństwo i islam, ale oskarżenia o separatyzm i terroryzm mogą odnosić się także do buddyzmu tybetańskiego. Mimo wspomnianych wyżej pozytywnych funkcji religii, nadal jest ona przedstawiana jako zagrożenie, które może zostać zneutralizowane tylko przez sinizację.

Czym więc jest i na czym ma polegać ,sinizacja”, która odnosi się nawet do rdzennie chińskiego taoizmu? Oznacza ona przede wszystkim całkowite zaakceptowanie przez wszystkie religie w ChRL zwierzchnictwa partii nad sobą, lojalność wobec państwa ponad lojalnością wobec religii i doktrynalne dopasowanie się do socjalistycznej interpretacji kultury chińskiej tak współczesnej, jak i tradycyjnej. Wszystkie te kwestie są bardzo silnie z sobą powiązane i wszystkie ostatecznie muszą dotykać kwestii doktrynalnych. Dopasowanie się do nich z praktycznego punktu widzenia nie jest oczywiście niemożliwe. Prowokuje to jednak do następującego pytania: czy religie, które muszą w interpretowaniu własnej doktryny kierować się ideologicznymi wskazówkami narzuconymi im przez władze nie tylko świeckie, ale wręcz programowo ateistyczne, mają szansę tworzyć własną propozycję światopoglądową? Odpowiedź na to pytanie jest trudna, można w każdym razie stwierdzić, że tak rozumiana sinizacja przysporzy mniej trudności religiom od tysiącleci zadomowionym w Chinach jak taoizm i buddyzm, które rozwijały się (szczególnie w ostatnich wiekach cesarstwa) w takich właśnie warunkach państwowej kontroli i - co równie ważne - nie mają koncepcji jednego, stojącego ponad światem Boga. Funkcjonujący w Chinach od stuleci islam także wypracował już własny model współistnienia z kulturą i państwem chińskim, ale ostatnie lata światowej ekspansji islamu i lęk Chin przed kojarzonymi z nim „ekstremizmem i separatyzmem” wprowadziły poważne zaburzenia w relacji na linii islam-państwo. Najkrócej działające w Chinach chrześcijaństwo, zarówno katolicyzm, jak i protestantyzm, ma za sobą przynajmniej stulecie intensywnego i bardzo trudnego dopasowywania się do warunków chińskich po upadku cesarstwa. Niełatwo stwierdzić, co ostatecznie przyniesie mu ta najnowsza fala ,sinizacji”.

Dla zilustrowania takiej próby odniesienia postulatu sinizacji do chrześcijaństwa (a ściślej - protestantyzmu) poniżej podajemy fragmenty artykułu „Kilka rozważań nad kwestią sinizacji chrześcijaństwa” („Jidujiao zhongguo"). Autor rozpoczyna od krytycznej analizy współczesnej sytuacji i stopnia zaawansowania sinizacji, podkreślając problem wzajemnego poczucia 
obcości między chrześcijaństwem a kulturą chińską: „Chociaż sinizacja chrześcijaństwa przyniosła już widoczne rezultaty, (...) wciąż przez wielu uważane jest ono za religię obcą i cudzoziemską, a w kościele nadal znajdują się ludzie, którzy uważają kulturę chińską za pogańską, a kulturę socjalistyczną za heretycką” („Jidujiao zhongguo”; tłum. pol. M.R.).

Prowadząc ten wątek dalej, autor akcentuje zachodni charakter chrześcijaństwa, i to w taki sposób, jakby był on wyłącznie źródłem zagrożenia i wrogości między chrześcijaństwem a Chinami i narzędziem wykorzystywanym przez Zachód do infiltracji i kontrolowania Chin od zewnątrz i od wewnątrz:

Wrogie siły zachodnie nadal wykorzystują chrześcijaństwo do prób westernizacji Chin, a niektóre zagraniczne organizacje religijne usiłują powrócić do Chin, odzyskać dawne przywileje i kontrolę nad naszą religią. (...) Chińscy chrześcijanie nadal stoją na stanowisku pierwszeństwa kultury zachodniej przed chińską i potrzeby całkowitej westernizacji, a także szukają w chrześcijaństwie nowego źródła wartości dla Chin. (...) Niektóre państwa zachodnie wykorzystują chrześcijaństwo w celu penetracji Chin, usiłują podbić „chińskiego smoka” przy pomocy „Chrystusowego baranka” i dokonać całkowitej ewangelizacji Chin. (,Jidujiao zhongguo”; tłum. pol. M.R.)

Ostatecznie autor stwierdza, że chrześcijaństwo musi stać się „prawdziwie chińskie" pod względem politycznym, kulturalnym, społecznym i teologicznym. Omawiając punkt ostatni, najpierw krytykuje postawę współczesnych chińskich teologów, których prace „nie dotyczą spraw rzeczywistości chińskiej” i którzy „padają na twarz przed religijnymi patriarchami z Zachodu", a w dalszym fragmencie stwierdza, że

sinizacja teologii oznacza połączenie jej z kulturą chińską i chińską rzeczywistością społeczną. (...) Kościół chiński wzrastał w Nowych Chinach, w szczególności na drodze praktyki Patriotycznego Ruchu Trzech Niezależności. Musi on sformułować idee korzystne dla rozwoju prawdziwie chińskiego kościoła, zbudować ideologiczny system teologii z chińską specyfiką, wypracować własne świadectwo zgodne $\mathrm{z}$ sytuacją kulturalno-społeczną i promować postęp sinizacji chrześcijaństwa. (...) Jeśli chcemy zbudować idealne chińskie chrześcijaństwo, kościół musi na nowo narodzić się w chińskiej kulturze. (Ibid.)

Wezwanie do stworzenia nowej, „prawdziwie chińskiej” teologii nasuwa pewne skojarzenia historyczne. Można by zadać pytanie, czy powstające w Chinach w XX wieku oddolne, spontaniczne i autentycznie rodzime ruchy protestanckie, których najważniejszym przykładem są „kościoły miejscowe”, 
zapoczątkowane przez Watchmana Nee (1903-1972) i Witnessa Lee (19051997), które rzeczywiście niosły swoje „własne świadectwo”, są czy nie są właściwym przykładem „prawdziwie chińskiej teologii”? Zważywszy, że działalność tych ruchów pozostaje w Chinach zakazana, ich świadectwo nie spełnia warunków „sinizacji”. Pozostawia to otwartym pytanie o kierunek nowej „teologii z chińską specyfiką” powstającej na zamówienie i pod dyktando władzy, a także o to, czy i na ile odgórnie sterowane ulokalnienie Kościoła rzeczywiście może się powieść.

Uznanie polityki religijnej za ważny element całości polityki państwa pokazuje, że Chiny traktują tę sprawę poważnie. W swoich przemówieniach Xi Jinping szczególnie podkreśla przewodnictwo partii w polityce religijnej i konieczność „dobrego, wnikliwego i prawidłowego” przemyślenia tego przewodnictwa. Partia nie może zostawić religii samym sobie - musi im przewodzić, musi je kontrolować zarówno od zewnątrz za pomocą prawa, jak i od wewnątrz, przez wychowanie lojalnych „kadr religijnych” i przez wskazanie religiom, jak i czego mają nauczać. Kierunek chińskiej polityki religijnej w ostatnich czterdziestu latach to stopniowe poszerzanie kontroli państwa $\mathrm{w}$ sferze religii i jednoczesne uszczegółowianie obszarów i doskonalenie narzędzi tej kontroli.

Potrzeba jak najszerszej i jak najbardziej szczegółowej kontroli nad religiami może być o tyle zrozumiała, że Chiny jako państwo wielowyznaniowe rzeczywiście nie mogą sobie pozwolić na wewnętrzne zagrożenie konfliktami na tle religijnym. Pozostaje jednak pytanie o charakter tej kontroli. Postępująca regulacja prawna sytuacji religii jest oczywiście koniecznością. Umożliwia ona organizacjom i grupom religijnym otrzymanie statusu prawnego i prawa do świadczeń, przede wszystkim jednak ma eliminować jakąkolwiek przypadkowość decyzji ze strony władz i nie dopuszczać do niekontrolowanych, spontanicznych przejawów życia religijnego. Z drugiej strony jednak prawo ma służyć jako broń przeciwko „klice Dalaj Lamy” i narzędzie ,uporządkowania sytuacji w klasztorach (tybetańskich) sprawiających szczególne problemy”. Ma również dopomóc w „walce z ekstremizmem” oraz „uniemożliwić generalizowanie pojęcia halal i wykorzystywanie go do ingerowania w administrację, prawodawstwo i edukację". Wszelkie niejasności i punkty sporne w relacji państwa i religii mają znaleźć odbicie w chińskim prawodawstwie, a to oznacza przynajmniej jasne nakreślenie sfer dozwolonego i niedozwolonego działania i zapewnienie wiernym ochrony dopóki znajdują się w strefie dozwolonej. Prawo ma też ostatecznie 
doprowadzić do „uporządkowania sytuacji prywatnych zgromadzeń w protestantyzmie" (,Dang de shiba da yilai”).

Obowiązkowa „sinizacja”, która obejmuje nawet rdzennie chiński taoizm i która w gruncie rzeczy oznacza kompletną instytucjonalną uległość wobec państwa, jest - wbrew deklaracjom - ingerencją w „wewnętrzne sprawy religii”. To państwo i partia decydują, czy religia jest dostatecznie ,zsinizowana" i czy sinizacja przebiega prawidłowo. Jest to - znowu wbrew deklaracjom - wyraźny zwrot w kierunku zaostrzenia kontroli i nowa korekta w chińskiej polityce religijnej.

\section{BIBLIOGRAFIA}

„Dang de shiba da yilai zongjiao gongzuo lilun he shijian chuangxin 党的十八大以来宗教工作理 论和实践创新” | thum. pol. (M.R.): „Innowacje w teorii i praktyce pracy religijnej po XVIII Zjeździe KPCh”, Zhonggong guojia zongjiao shiwu ju dangzu lilun xuexí zhongxin zu 中共国 家宗教事务局党组理论学习中心组 | Centralna grupa studiów teoretycznych KC i organizacji partyjnej Rady Państwa, 15.09.2017. Qiushi 求是, www.qstheory.cn/dukan/qs/2017-09/15/c_ 1121647553.htm. Dostęp 8.06.2020.

”Guanyu woguo shehui zhuyi shiqí zongjiao wentí de jiben guandian he jiben zhengce 矢于我国社 会主义时期宗教问题的基本观点和基本政策” | thum. pol. (M.R.): „Podstawowe poglądy i podstawowe wytyczne w odniesieniu do kwestii religijnych w Chinach w okresie socjalizmu", cpc.people. com.cn/GB/64184/64186/66704/4495674.html. Dostęp 8.06.2020.

„Guojia zongjiao shiwuju dangzu lilun xuexí zhongxin zu: Fahui zangjiao jie de jiji zuoyong 国家 宗教事务局党组理论学习中心组：发挥宗教界的积极作用” | thum. pol. (M.R.): Centralna grupa studiów teoretycznych KC i organizacji partyjnej Rady Państwa: „Odgrywanie pozytywnej roli przez religie”, 19.06.2014. Zhongguo Minzubao 中国民族报, www.sara.gov.cn/old/ llyj/ 86760.htm. Dostęp 8.06.2020.

„Jianchi makesizhuyi yu jianchi kexue wushenlun 坚持马克思主义与坚持科学无神论”| thum. pol. (M.R.): „Utrzymanie marksizmu i naukowego ateizmu”, 07.07.2010. Zongjiao yu shijie 《宗教 与世界》t. 4, 2010, www.sara.gov.cn/zjbk/ llyj2017 0904195404515538/457252.htm. Dostęp 8.06.2020.

„Jiaqiang dang dui zangjiao gongzuo de lingdao 加强党对宗教工作的领导” | thum. pol. (M.R.): „Wzmacnianie przewodniej roli Partii w pracy religijnej”, 12.08.2014. Zhongguo Minzubao 中 国民族报, www.sara.gov.cn/old/ zzjg/zjwhcbs/jcsp13/124002.htm.

„Jidujiao zhongguohua wenti de ji dian sikao 基督教中国化问题的几点思考”| thum. pol. (M.R.): „Kilka rozważań nad kwestią sinizacji chrześcijaństwa (protestantyzmu)”, 14.03.2016. Guojia Zongjiao Shiwujun Yanjiu Zhongxin 国家宗教事务局研究中心, www.sara.gov.cn/zjbk/ 1 y20170904 195404515538/457302.htm. Dostęp 8.06.2020.

„Nian quanguo zongjiao juzhang huiyi zai Jing zhaokai Wang Zuo'an juzhang fayan 年全国宗教局 长会议在京召开 王作安局长发言”| tłum. pol. (M.R.): Przemówienie dyrektora Wang Zuo'ana na Ogólnokrajowej Konferencji dyrektorów departamentów religii 2018. Huang wang guang ci 凰網廣束, http://gd.ifeng.com/a/201 80109/6290428_0.shtml. Dostęp 8.06.2020. 
„Ruhe jiedu woguo zongjiao zhongguohua 如何解读我国宗教中国化” | thum. pol. (M.R.): „Jak rozumieć sinizację religii w naszym kraju?”. Tongzhan Xinyu 统战新语, 14.062016, www. zytzb.gov.cn/tzb2010/wxwb/201606/004b224588914f478cdddb54a538d18b.shtml. Dostęp 8.06. 2020.

„Shehui zhuyi de zongjiao lun xíngcheng de lishi tiaojian 社会主义的宗教论形成的历史条件” | thum. pol. (M.R.): „Historyczne uwarunkowania kształtowania się socjalistycznego poglądu na religię", 11.11.2005. Zhongguo Zongjiao 中国宗教, www.sara.gov.cn/zjbk/llyj201709041954 4515538 457212.htm. Dostęp 8.06.2020.

„Shehuizhuyi de zongjiao lun 社会主义的宗教论” | thum. pol. (M.R.): „Socjalistyczny pogląd na religię", 11.11.2005. Zhongguo Zongjiao 中国宗教, www.sara.gov.cn/zjbk/llyj201709041954 04515538/ 457233.htm. Dostęp 8.06.2020.

”《Shahuizhuyi de zongjiao lun» xingcheng de lishi tiaojian 社会主义的宗教论形成的历史条件” thum. pol. (M.R.): „Uwarunkowania historyczne kształtowania się socjalistycznej teorii religii”, 11.11.2005. Zhongguo Zongjiao 中国宗教, www.sara.gov.cn/zjbk/llyj201709041954045155 38/ 457212.htm. Dostęp 8.06.2020.

„The People's Republic of China: Document 19: The Basic Viewpoint on the Religious Question During Our Country's Socialist Period (selections)". International Center for Law and Religion Studies, www.religlaw.org/content/religlaw/documents/doc19relig1982.htm. Dostęp 8.06. 2020.

„White paper on Religion Freedom of Religious Belief in China”, china.org.cn, www.china.org.cn/ e-white/Freedom/index.htm. Dostęp 8.06.2020.

„Xi Jinping chuxi quanguo zongjiao gongzuo huiyi bing fabiao zhongyao jianghua 习近平出席全 国宗教工作会议并发表重要讲话”| thum. pol. (M.R.): „Ważne przemówienie Xi Jinpinga na Ogólnokrajowej Konferencji Pracy Religijnej”, people.cn, politics.people.com.cn/n1/2016/04 23/ c1001-2829 9513.html. Dostęp 8.06.2020.

„Xin shidai ruhe jianchí woguo zongjiao de zhongguohua fangxiang? Xian gao qingchu zhe 5 dian 新时代如何坚持我国宗教的中国化方向？先搞清楚这5点”| thum. pol. (M.R.): „Jak utrzymać kierunek sinizacji religii w naszym kraju w nowej erze? Objaśnienie pięciu punktów", www.cwzg.cn/theory/201711/39646.html. Dostęp 8.06.2020.

„Zhizhang dang yu zongjiao: Yige jiqi zhongyao de lilun wenti 执政党与宗教：一个极其重要的 理论问题” | tłum. pol. (M.R.): „Partia rządząca a religia - problem teoretyczny o ogromnym znaczeniu”, 11.11.2005. Zhongguo Zongjiao 中国宗教, www.sara.gov.cn/zjbk/llyj2017090 41954045 15538/457223.htm. Dostęp 8.06.2020.

„Zhonggong zhongyang guowuyuan guanyu jiaqiang zongjiao gongzuo de jueding 中共中央国务 院关于加强宗教工作的决定” | thum. pol. (M.R.): Decyzja Komitetu Centralnego Komunistycznej Partii Chin i Państwowej Rady ds. zintensyfikowania pracy religijnej, 360doc.com, www.360doc.com/ content/17/0815/08/10500687_679286984.shtml. Dostęp 8.06.2020.

„Zhongguo baozhang zongjiao xinyang ziyou de zhengce he shijian 中国保障宗教信仰自由 的政 策和实践 | thum. pol. (M.R.): „Wytyczne i praktyka gwarancji wolności religii i wyznania w Chinach”. Zhonghua renmin gongheguo guowuyuan xinwen bangongshi 中华人民共和国国 务院新闻办公室, www.scio.gov.cn/zfbps/32832/Document/1626514/1626514.htm. Dostęp 8.062020 .

„«Zhongguo baozhang zangjiao xinyang ziyou de zhengce he shijian» baipishu xinwen fabu hui zai Jing juxing 《中国保障宗教信仰自由的政策和实践》白皮书新闻发布会在京举行”| thum. pol. (M.R.): Konferencja Prasowa w Pekinie na temat Białej księgi „Wytyczne i praktyka gwarancji wolności religii i wyznania w Chinach”, 3.04.2018, www.sara.gov.cn/xwfb/xwjj2017 09050936183 59691/581898.htm. Dostęp 8.06.2020. 
„Zhongguo tese shehuizhuyi zongjiao lilun de tansuo licheng 中国特色社会主义宗教理论的探索 历程” | thum. pol. (M.R.): „Historia socjalistycznej teorii religii z chińską charakterystyką”, 2014-04-01. ,Zhongguo tese shehui zhuyi zongjiao lilun xuexi deben” jiexuan zhi san 《中国特 色社会主义宗教理论学习读本》节选之三. Wybrane fragmenty $\mathrm{z}$,Podręcznika socjalistycznej teorii religii z chińską charakterystyką", cz. 3. Zhongguo Minzubao 中国民族报, www.sara. gov.cn/old/xwzx/xwjj/63729.htm. Dostęp 8.06.2020.

Zhu, Xiaoming. „On the Socialist View on Religion with Chinese Characteristics”. Marxism and Religion, red. Gong Xuezeng, Lü Daji. Brill, 2014, ss. 348-375.

\section{WSPÓŁCZESNA POLITYKA CHIN WOBEC RELIGII}

\section{Streszczenie}

Ostatnie czterdzieści lat reform i otwarcia w Chinach przyniosło wiele zmian i poprawek w polityce państwa chińskiego wobec religii. Została ona włączona do ogólnej polityki państwa i uznana za ważną część pracy partii. Podstawą teoretyczną państwowej polityki religijnej jest „Teoria religii o cechach chińskich”. W 2015 r. Xi Jinping po raz pierwszy stwierdził potrzebę „uporczywości w sinizacji religii”. Jego rozumienie „sinizacji” dotyczyło nie tylko religii obcych, takich jak islam czy chrześcijaństwo, ale także rdzennego daoizmu, co oznacza, że we współczesnym oficjalnym języku ChRL termin „sinizacja religii” ma nowe znaczenie, różni się od bardziej tradycyjnego rozumienia tego słowa. W rzeczywistości został przetłumaczony na publikacje w języku angielskim jako „chińskie wyznanie religii”; jeszcze bardziej stosownym thumaczeniem byłaby jednak „ChRLizacja religii”, ponieważ „sinizacja” oznacza przede wszystkim posłuszeństwo zasadom KPCh i „dostosowanie się do potrzeb społeczeństwa socjalistycznego”. W tym artykule zarysowano ewolucję teorii religii z chińskimi cechami, tak jak jest ona rozumiana i prezentowana w oficjalnych publikacjach, oraz spróbowano przeanalizować zakres założonej „sinizacji religii” we współczesnych Chinach.

Słowa kluczowe: religia w Chinach; sinizacja religii; teoria religii o cechach chińskich; Xi Jinping;

Chińska polityka religijna; religia i polityka w Chinach. 